\title{
Decomposition of Leaf Litter in Semideciduous Submontane Forest, in The Southern State of Espírito Santo
}

\author{
Diêgo Gomes Júnior ${ }^{1}$ (D), Marcos Vinicius Winckler Caldeira ${ }^{2}$ (D), \\ Valéria Hollunder Klippel², Eduardo De Sá Mendonça², \\ William Macedo Delarmelina ${ }^{3}$, Tiago De Oliveira Godinho ${ }^{4}$ (D), \\ Rafael Luiz Frinhani Rocha ${ }^{5}$ \\ ${ }^{1}$ Instituto de Defesa Agropecuária e Florestal do Espírito Santo, Alegre/ES, Brasil \\ ${ }^{2}$ Universidade Federal do Espírito Santo - UFES, Alegre/ES, Brasil \\ ${ }^{3}$ Instituto Federal de Educação, Ciência e Tecnologia do Espirito Santo, Ibatiba/ES, Brasil \\ ${ }^{4}$ Vale S.A., Linhares/ES, Brasil \\ ${ }^{5}$ Universidade Estadual do Norte Fluminense Darcy Ribeiro, Campos/RJ, Brasil
}

\begin{abstract}
The objective of this work was to understand the relationship between decomposition of leaf litter and climatic elements and determine the mineralization of nutrients in the decomposition process in a fragment of Semideciduous Submontane Forest, located in southern state of of Espírito Santo. Overall, 84 litterbags were deposited in 12 permanent plots, collecting one litterbag per plot for $30,60,90,150,210,270$ and 360 days after the beginning of the experiment. The leaf material remaining in the litterbag was oven-dried and weighed, with later analysis of nutritional compounds. The leaf litter decomposition rate was $1.42,75.95 \%$ of decomposing litter at the end of the evaluation period. Mineralization occurred in the following order: $\mathrm{K}, \mathrm{C}_{\text {org }}, \mathrm{Mg}, \mathrm{S}, \mathrm{P}$, $\mathrm{N}$ and $\mathrm{Ca}$. There was a positive correlation of average and minimum air temperature, as well as accumulated precipitation and leaf litter decomposition .
\end{abstract}

Keywords: nutrient cycling, tropical forests, macronutrients, lignocellulosic compounds. 


\section{INTRODUCTION AND OBJECTIVES}

Atlantic Forest (AF) is one of the richest and most threatened ecosystems on the planet. Located mainly on the Brazilian coast, the Atlantic Forest covers many types of tropical ecosystems and has one of the largest biodiversities and endemism in the world (Myers et al., 2000; Ribeiro et al., 2009). For sheltering considerable portion of the Brazilian biodiversity, it presents high endemism of species, and for being seriously affected by anthropic action, $\mathrm{AF}$ was recognized as a priority area for conservation -- a hotspot (Myers et al., 2000).

In natural environments, mainly in tropical environments such as AF, soil is not the main route of supply of nutrients to the vegetation (Calvi et al., 2009; Menezes et al., 2010; Diniz et al., 2011). In these environments, where soil is very weathered, the process of nutrient cycling performs connection between production cycles and organic matter decomposition, becoming the main route of return of nutrients and organic matter to the soil (Caldeira et al., 2013; Godinho et al., 2013a). Thus, organic matter decomposition is one of the most important ecological processes that occur in terrestrial ecosystems. It is defined as a biological process of organic matter breakdown that promotes the transformation of organic compounds into inorganic compounds (Barbhuiya et al., 2008).

The organic matter and litter decomposition rate, as well as its quantitative and qualitative analysis, are important aspects for the understanding of ecosystems, due to their role in the maintenance of ecosystems in tropical soils (Alves et al., 2006). Liter decomposition is the result of the interaction of climatic conditions, plant residue composition and the decomposing fauna (Bauer et al., 2016). Such interaction will determine the litter decomposition rate over time, which may be higher or lower in different ecosystems.

With the purpose of understanding to what extent environmental disturbance, either by natural or anthropogenic factors, has affected the functioning of ecosystems, several studies have been developed considering different forestry aspects, raising qualitative and quantitative data on the state of sufficiency of forests based on their nutritional status (Rumpel\&Kögel-Knabner, 2011; Franco et al., 2016; Joslin et al., 2016). Among these studies, those dealing with leaf decomposition and nutrient cycling stand out, considered regulatory processes for the functioning and development of a forest ecosystem (Nogueira et al., 2011; Neto et al., 2013; Holanda et al., 2015; Machado et al., 2015; Gilliam et al., 2016).

However, despite the importance given to studies on leaf litter decomposition, they have not provided data on the correlation between decomposition and climatic elements, i.e., discussions on the relationship of decomposition rate with these elements are based on descriptive methods in the majority of studies (Silva et al., 2013; Lima et al., 2015). As exposed above, it is believed that leaf litter decomposition is directly influenced by climatic variations over time in tropical regions.

Thus, the objective of this work was to understand the relationship between leaf litter decomposition and climatic elements and determine the mineralization of nutrients in the decomposition process in a fragment of Semideciduous Submontane Forest located in southern state of Espírito Santo.

\section{MATERIAL AND METHODS}

The study area is located at "Reserva Particular do Patrimônio Natural” (RPPN) Boa Esperança Farm, municipality of Cachoeiro de Itapemirim, Southern state of Espirito Santo (coordinates UTM/Sirgas2000 268275,48 E; 7707754,70 N) (Figure 1a). Inserted in the Itapemirim River Basin, RPPN has total area of 517 ha, being composed of four forest fragments. This work was carried out in a fragment of greater representation, with area of 358.86 ha, which integrates the "Burarama - Pacotuba - Cafundó" ecological corridor, inside Atlantic Forest biome.

The climate of the region, according to the Köppen classification, is of Aw type (tropical with dry season in the winter) (Alvares et al., 2013). Precipitation data, both in the study period and historical series (1987 - 2016), were obtained at the National Water Agency station (ANA) (02041002), located in the municipality of Castelo - ES, approximately $12 \mathrm{~km}$ away from the study area, whereas temperature data were obtained from the meteorological station of the National Institute of Meteorology automatic surface (INMET) (Alegre-A617), located in the municipality of Alegre - ES, approximately $26 \mathrm{~km}$ away of the study area. The history of monthly averages for this variable was obtained from the same station, in the period from 2006 to 2016 (Figure 2). 




Figure 1. Location of the study area (a) and the 12 permanent plots used (b).

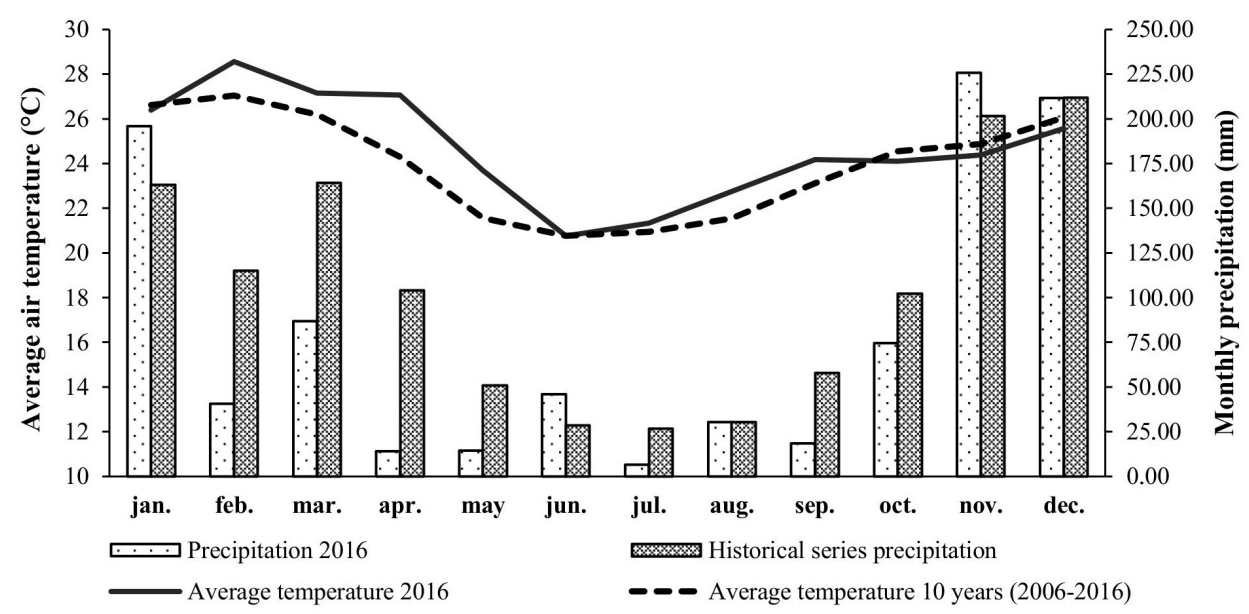

Figure 2. Average values of climatic elements during the leaf decomposition period and historical series of RPPN Boa Esperança Farm, Cachoeiro de Itapemirim, ES.

The predominant soil in the forest fragment under study is Planosol Haplic Eutrophic Sandy, originated from gneissic material and Hydro morphism process, with inclusion of Dystrophic Red-Yellow Latosol and Typical Eutrophic Tb Haplic Cambisol (Gomes, 2017). In general, the superficial soil layer has sandy texture with a low acid character and medium fertility (Table 1), with vegetation above it classified as Semideciduous Submontane Forest (Delarmelina, 2015). In a study on the structure of the arboreal component of this fragment, Archanjo et al. (2012) observed high richness of secondary species and low density of initial succession groups, indicating a well preserved forest fragment with advanced succession stage. 
Table 1. Litter (April/15 - March/16) and physico-chemical attributes of the soil $(0-20 \mathrm{~cm})$ in Semideciduous Sub montane Forest, Cachoeiro de Itapemirim, ES.

\begin{tabular}{lr}
\multicolumn{1}{c}{ Parameters } & Values \\
\hline Liter $\left(\mathrm{kg} \mathrm{ha}^{-1} \mathrm{year}^{-1}\right)$ & \\
Deposited & 5741.45 \\
Accumulated & 5079.44 \\
Soil attributes & \\
$\mathrm{pH}\left(\mathrm{H}_{2} 0\right)$ & 5.98 \\
$\mathrm{P}\left(\mathrm{mg} \mathrm{dm}^{-3}\right)$ & 7.24 \\
$\mathrm{~K}\left(\mathrm{mg} \mathrm{dm}^{-3}\right)$ & 64.70 \\
$\mathrm{Ca}\left(\mathrm{cmol}_{\mathrm{c}} \mathrm{dm}^{-3}\right)$ & 4.38 \\
$\mathrm{Mg}\left(\mathrm{cmol}_{\mathrm{c}} \mathrm{dm}^{-3}\right)$ & 1.16 \\
Sum of Bases $\left(\mathrm{cmol}_{\mathrm{c}} \mathrm{dm}^{-3}\right)$ & 5.70 \\
Effective CTC $\left(\mathrm{cmol}_{\mathrm{c}} \mathrm{dm}^{-3}\right)$ & 5.75 \\
\hline Bases saturation $(\%)$ & 65.60 \\
\hline Organic matter $\left(\mathrm{g} \mathrm{dm}^{-1}\right)$ & 33.95 \\
Density $\left(\mathrm{kg} \mathrm{dm}^{-3}\right)$ & 1.15 \\
Coarse Sand $\left(\mathrm{g} \mathrm{kg}^{-1}\right)$ & 493.67 \\
Thin Sand $\left(\mathrm{g} \mathrm{kg}^{-1}\right)$ & 178.43 \\
Silt $\left(\mathrm{g} \mathrm{kg}^{-1}\right)$ & 65.94 \\
\hline Clay $\left(\mathrm{g} \mathrm{kg}^{-1}\right)$ & 261.97 \\
\hline
\end{tabular}

Source: Delarmelina (2015) and Gomes (2017).

For the study on leaf litter decomposition, the method of litterbags proposed by Bocock\& Gilbert (1957) was used. Overall, 84 litterbags with dimensions of $25 \times 25 \mathrm{~cm}$, in $2 \mathrm{~mm}$ nylon mesh were manufactured. The foliar plant material used to fill Litterbags was obtained in the months of November and December 2015 through the collection of litter deposited in collectors installed in 12 permanent plots $(20 \times 50 \mathrm{~m})$, demarcated in the study of Archanjo et al. (2012) (Figure 1b), distributed in a systematic way in the field. This material was submitted to kiln drying air circulation at $65^{\circ} \mathrm{C}$ for 72 hours, and subsequently $20 \mathrm{~g}$ were packed in each litterbag. Litterbags were systematically installed at the center of each of the 12 permanent plots (seven litterbags/plot) on the forest ground.

For determination of the decomposition constant, litterbags installed on plots in January 2016 were collected in 30,60, 90, 150, 210, 270 and 360 days after installation, being collected one litterbag/plot, totaling 12 litterbags/ decomposition period evaluation. After collection, litterbags were submitted a cleaning process with the aid of tweezers and brush for the removal of materials like roots, insects, soil, or other material not originated from the leaf fraction. Then, the material was submitted to drying with air circulation at $65^{\circ} \mathrm{C}$ for 72 hours, for later weighing in precision analytical scale. After weighing, the leaf plant material for each collection period was mixed and ground in Willey type mill with $1 \mathrm{~mm}$ mesh (20 mesh), separating three samples per evaluation period for the determination of the ash content, nutritional analysis and determination of the levels of lignin, cellulose and hemicellulose. These same parameters were also determined in three samples of the plant material before beginning of the experiment ( 0 days). The percentage of dry weight of leaf litter remaining after each collection was calculated as proposed by Guo \& Sims (1999) (Equation 1).

$W_{\%}=\frac{W_{t}}{W_{0}} \times 100$

Where: $\mathrm{W}_{\%}$ is the percentage of dry weight of remaining leaf litter; $W_{t}$ is the dry weight of remaining leaf litter in the decomposition bag at time $\mathrm{t}(\mathrm{g})$; and $\mathrm{W}_{0}$ is the initial dry weight of leaf litter in the decomposition bag (g).

The ash content (Carvalho et al., 2008), which is the amount of inorganic material present in the plant material, was determined after total incineration of the plant material in muffle (Equation 2).

$T c=\left(\frac{P a c-P c}{P a s}\right) \times 100$

Where: Tc is the ash content (\%); Pac is the weight of ash + crucible $(\mathrm{g})$; PC is the weight of the crucible (g); and Pas is the weight of the dried sample (g).

Using the ash content of initial plant material (0 days) and the decomposition times, the percentage of dry weight of leaf litter was recalculated, discounting the increase of the ash content in each decomposition time. After determination, the decomposition constant (k) of leaf litter, discounting the ash content, was obtained by the exponential equation proposed by Olson (1963) (Equation 3).

$W_{t}=W_{0} \cdot e^{-K t}$

Where: $W_{t}$ is the dry weight of the leaf litter remaining in the decomposition bag at time $\mathrm{t}(\mathrm{g}) ; \mathrm{W}_{0}$ is the initial dry weight of leaf litter remaining in the decomposition bag $(\mathrm{g})$; and $\mathrm{K}_{\mathrm{t}}$ is the annual decomposition constant.

In the chemical analysis of plant material for obtaining the leaf macronutrient content, $\mathrm{N}$ was extracted by means of sulfuric acid digestion and determined by Kjeldahl distiller, while the other nutrients were extracted by 
means of nitric perchloric digestion, being $\mathrm{P}$ and $\mathrm{S}$ determined by optical spectrophotometry, and $\mathrm{K}, \mathrm{Ca}$ and $\mathrm{Mg}$ determined by atomic absorption spectrophotometry (Tedesco et al., 1995). The organic C content was determined by means of LECO elemental analyzer model C-144 (Leco, 2008). The nutrient mineralization rate in decomposition times was obtained according to Guo \& Sims (1999) (Equation 4).

$R_{\%}=\frac{W_{0} C_{0}-W_{t} C_{t}}{W_{0} C_{0}} \times 100$

Where: $\mathrm{R}_{\%}$ is the nutrient mineralization rate (\%); $\mathrm{W}_{0}$ is the initial dry weight of the plant material $(\mathrm{g}) ; \mathrm{C}_{0}$ is the initial nutrient content in the leaf plant material $\left(\mathrm{g} \mathrm{kg}^{-1}\right)$; $\mathrm{W}_{\mathrm{t}}$ is the dry weight of the plant material at the leaf decomposition time $(\mathrm{g})$; and $\mathrm{C}_{\mathrm{t}}$ is the nutrient content in the plant material remaining at the decomposition time $\left(\mathrm{g} \mathrm{kg}^{-1}\right)$.

To determine the levels of lignin, cellulose and hemicellulose, the ANKOM fiber analyzer 200 was used, according to Berchielli et al. (2001). Lignin analysis was performed by means of digestion of the residue of acid detergent fiber with $72 \%$ sulfuric acid, extracting cellulose and hemicellulose, and isolating lignin and inorganic matter. Hemicellulose levels were determined by means of differences between neutral detergent fiber and acid detergent fiber residues, while cellulose levels were determined by means of differences between Acid Detergent Fiber and lignin residues. Lignin levels were obtained by the difference between acid digestion and ash residue.

Analyses of data from leaf litter decomposition, lignin, cellulose and hemicellulose content, as well as $\mathrm{C} / \mathrm{N}$ and $\mathrm{C} / \mathrm{P}$ and $\mathrm{Lig} / \mathrm{N}$ ratios, were carried out by means of regression. To evaluate the influence of climatic elements in the leaf decomposition process, the Spearman correlation was applied between data from the remaining leaf mass and climatic elements (air temperature and precipitation) regarding the study period, using the R software (R Core Team, 2016).

\section{RESULTS}

The leaf litter mass decomposition during the evaluation period, discounting the ash content, was $75.95 \%$, resulting in decomposition constant $\mathrm{k}$ of 1.42 . The curve of remaining mass, generated by the leaf decomposition process, indicates that this process has exponential regression model, with fast beginning of mass loss (up to 90 days). In this initial period of the decomposition process, approximately $20 \%$ of leaf mass was decomposed in the first 30 days, reaching approximately $43 \%$ in 90 days. After this period, mass loss through decomposition reduced considerably, causing the half-life time, i.e., the time required to decompose $50 \%$ of leaf mass, which was 175 days. In addition, the variation amplitude among replicates (plots) in the decomposition process increased until 150 days, and reduced thereafter (Figure 3).

Correlating leaf mass decomposition with climatic elements, it was observed that the average temperature and the minimum air temperature positively correlated with decomposition in the collection period. When the period of days prior to the collection of the remaining material was considered, it was observed that, among air temperatures (average, minimum and maximum),

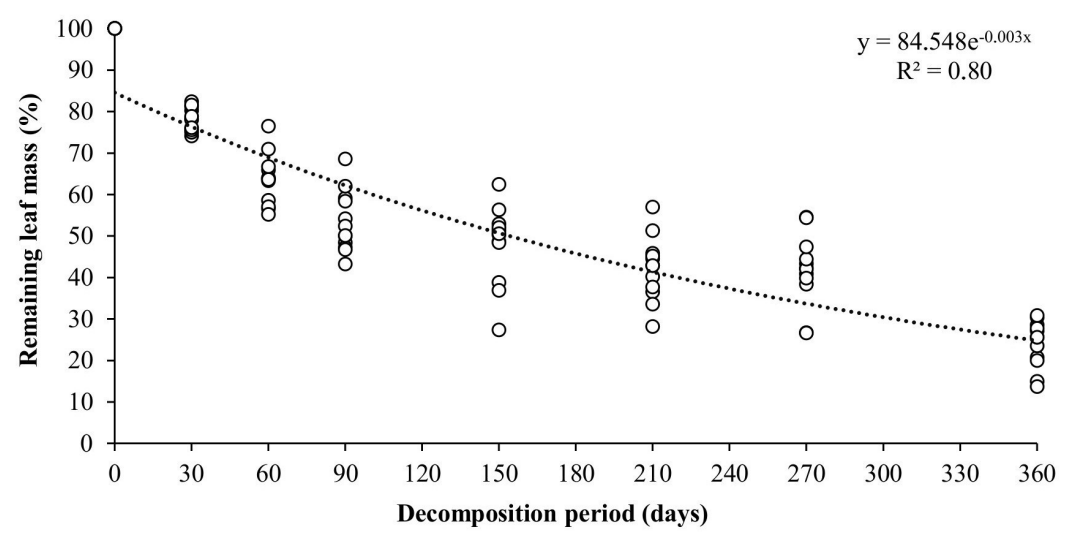

Figure 3. Remaining leaf mass throughout the decomposition period in Semideciduous Submontane Forest, Cachoeiro de Itapemirim, ES. 
only minimum temperature had positive correlation with decomposition and, even so, only when the period of 90 days prior to the collection of litterbags was considered (Figure 4).

Precipitation had a positive correlation with decomposition, considering its accumulation along 90 and 120 days prior to the collection of decomposing leaf mass. Observing the decrease of the correlation of air temperature (average, minimum and maximum) with leaf decomposition over time, it was observed that this element is associated with immediate responses in the decomposition process, while rainfall is associated with immediate responses in this process (Figure 4).

The mineralization of macronutrients and $\mathrm{C}_{\text {org. }}$ by leaf litter decomposition proved to be standardized throughout the decomposition process. Similarly to the leaf mass decomposition, macronutrients and $\mathrm{C}_{\text {org. }}$ had initial mineralization peak occurring up to 90 days of decomposition, showing a slow mineralization rate after this period. At 360 days of leaf litter decomposition, the descending order of nutrient mineralization was: $\mathrm{K}(92 \%), \mathrm{C}_{\text {org. }}$ (90\%), Mg (84\%), S (74\%), P (73\%), $\mathrm{N}(66 \%)$ and $\mathrm{Ca}(58 \%)$ (Figure 5).

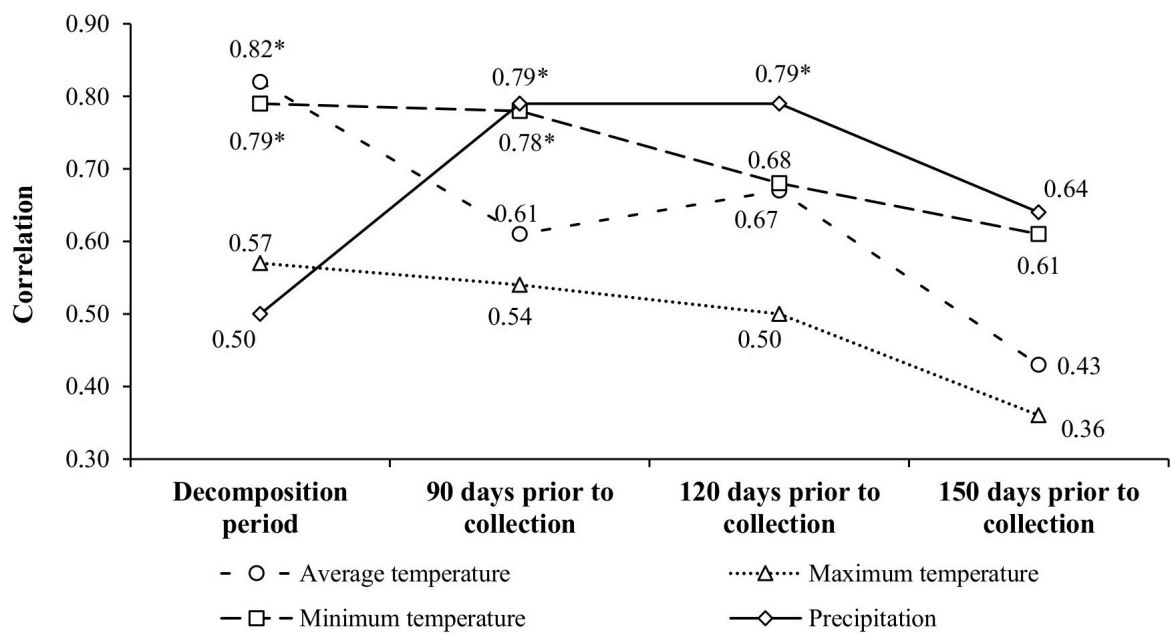

Figure 4. Spearman correlation between leaf mass decomposition and climatic elements in Semideciduous Submontane Forest, Cachoeiro de Itapemirim, ES. ${ }^{\star S i g n i f i c a n t ~ b y ~ t h e ~} \mathrm{t}$-test $(\mathrm{p} \leq 0.05)$.

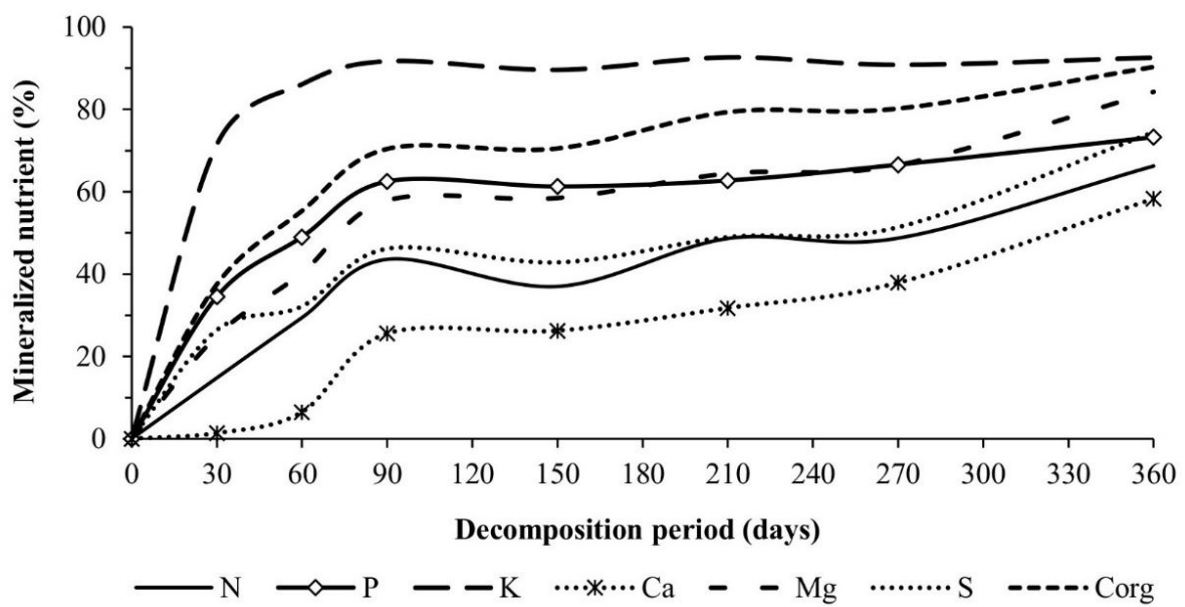

Figure 5. Mineralization of macronutrients and $\mathrm{C}_{\text {org. }}$ during the leaf litter decomposition evaluation period in Semideciduous Submontane Forest, Cachoeiro de Itapemirim, ES. 
During the evaluated decomposition period, the dynamics of structural components of the leaf mass was similar, so that lignin had regression curve slightly more pronounced than that of cellulose and hemicellulose. Such behavior considerably reduced the difference of lignin content in relation to cellulose and hemicellulose at the end of the decomposition period, indicating that lignin is degraded at a more accelerated rate than the other compounds (Figure 6).

The $\mathrm{C} / \mathrm{N}$ ratio decreased over the decomposition time, showing behavior similar to that of leaf mass with peak decrease until the 90 days of decomposition. Similar to the $\mathrm{C} / \mathrm{N}$ ratio, the $\mathrm{C} / \mathrm{P}$ ratio also decreased over time; however, this decrease occurred in a uniform way, with a slight increase between 210 and 270 days of decomposition. Unlike previous ratios, the lignin/N ratio had initial increase and remained virtually constant over the decomposition period (Figure 7).

\section{DISCUSSION}

The monitoring of litter decomposition in litterbags showed that the leaf decomposition rate observed in the period under study is in accordance with that estimated by Anderson et al. (1983) in neotropical forests, which varies from 1.1 to 1.7. However, the value

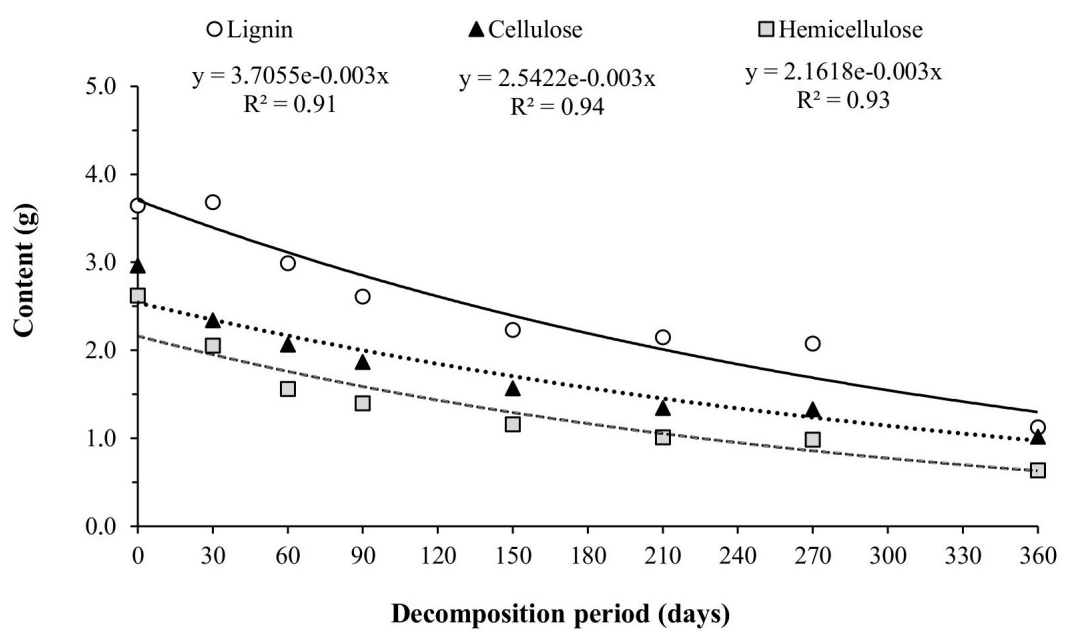

Figure 6. Lignin, cellulose and hemicellulose values in the remaining leaf mass during the decomposition evaluation period in Semideciduous Submontane Forest, Cachoeiro de Itapemirim, ES.

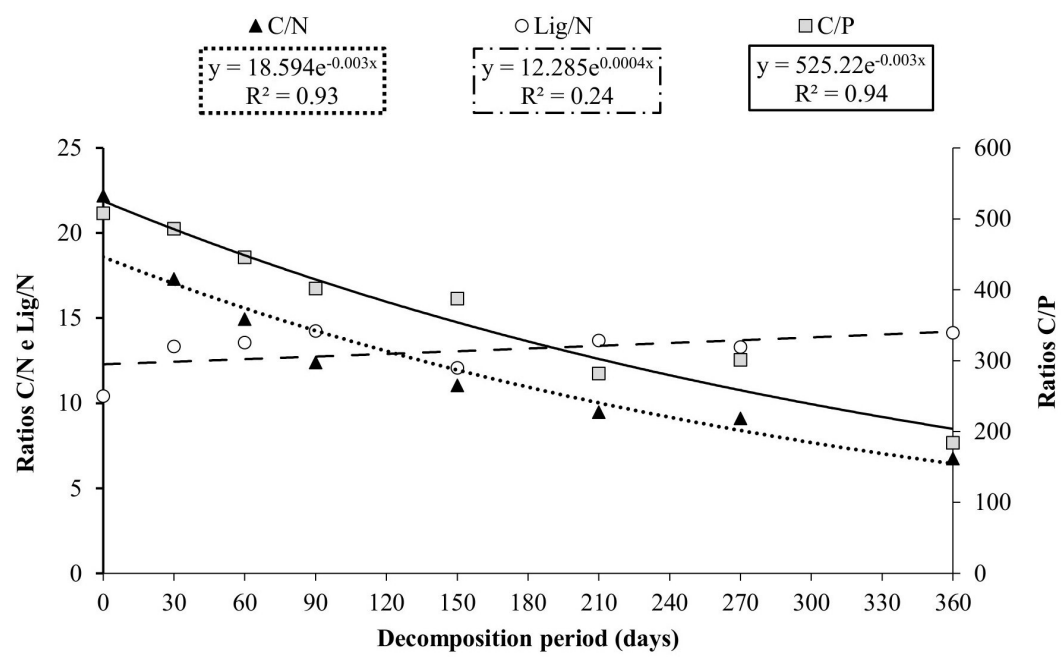

Figure 7. $\mathrm{C} / \mathrm{N}$ and $\mathrm{C} / \mathrm{P}$ and lignin/ $\mathrm{N}$ ratios in the remaining leaf litter mass in the decomposition process in Semideciduous Submontane Forest, Cachoeiro de Itapemirim, ES. 
found is above that observed by Silva et al. (2013) and Grugiki et al. (2017), both in Seasonally Dry Tropical Forest and in the secondary succession stage in Southern state of Espirito Santo. These variations are expected, since there is no homogeneity among tropical forest fragments in their attributes, either edaphic, climatic or biological. In addition, studies on leaf decomposition may have their results changed due to contamination of the material by soil, roots, soil fauna, among other contaminants from the environment (Scheer, 2008). According to Viera et al. (2014), the separation of impurities adhered to decomposing plant material is complex due to its fragmentation stage, being of utmost importance to consider this fact in order to better understand the decomposition process.

The decomposition curve obtained, with initial peak and subsequent smoothing, followed negative exponential simple model. Similar results were also verified by Silva et al. (2013) and Grugiki et al. (2017) in Atlantic Forest in southern state of Espírito Santo. Guimarães et al. (2009) and Sena et al. (2015) reported that nonlinear models are the best to describe biological parameters, since these parameters have hardly linear behavior. The initial peak in the decomposition process, with subsequent fall, occurs due to the rapid mineralization of some nutrients and organic compounds of greater solubility, and the fall in the process is justified by the influence of constituents of difficult decomposition, such as lignin, cellulose and hemicellulose (Berg, 2000).

Also in southern state of Espírito Santo, Grugiki et al. (2017) conducted a study with the objective of evaluating the decomposition and release of nutrients and microbial activity of leaf litter in forest cover of Acacia mangium, Sapindus saponaria, Hevea brasiliensis, and secondary forest. The authors found greater initial leaf litter decomposition in secondary forest and reported that this fact can be explained by the diversity of plant species, which influences the decomposition process since it affects the quality of the substrate (leaves and roots, mainly), the decomposition environment (microclimate) and, thus, the activity of the decomposing community.

Another important factor in the evaluation of litter decomposition, in addition to its biomass, is its nutrient content; therefore, litter is responsible for the retention of large amounts of nutrients, constituting an important form of return of mineral elements of vegetation to the soil, in its decomposition (Caldeira et al., 2008; Godinho et al., 2013a, 2013b). The degradation of animal and plant residues in the soil is a fundamental biological process to the ecosystem, in which carbon is recycled to the atmosphere as carbon dioxide, nitrogen becomes available as ammonia and nitrate, and other associated elements (phosphorus, sulfur and various micronutrients) assume inorganic forms and can then be assimilated by plants (Stevenson \& Cole, 1999).

The high $\mathrm{N}$ content and low $\mathrm{C} / \mathrm{N}$ ratio of leaf material propitiated the sharp initial decomposition, with consequent nutrient mineralization. The plant material that contains high $\mathrm{N}$ and $\mathrm{P}$ levels, as well as low amounts of lignin, cellulose and hemicellulose, have larger decomposition constant and nutrient mineralization (Rheinheimer et al., 2000; Majumder et al., 2010). However, there is variation in the mineralization of each nutrient during the decomposition of plant residues, as also observed by Viera et al. (2014).

In a study performed by Bachega et al. (2016), in Itatinga, SP, in the period in which the mixed planting of Eucalyptus grandis and Acacia mangium legume was between one to two years, the authors reported that the addition of nitrogen-fixing species in a eucalyptus monoculture may influence leaf litter decomposition. However, this fact depends on the establishment of a microbial community capable of breaking the constituents of both materials. The study area in Itatinga presented successive years with plant cover only of eucalyptus, which led to soil specialization and its community of decomposing microorganisms to act on its own litter considered recalcitrant and with high $\mathrm{C} / \mathrm{N}$ ratio.

The rapid mineralization of plant residue $\mathrm{K}$ occurs due to its easy leaching, for being free inside plant cells, since this is not a structural component of plant compounds (Costa et al., 2005; Scheer, 2008). In opposition, $\mathrm{Ca}$ has a delay in its mineralization process through decomposition, since this nutrient is a structural component of plant tissues, presenting low mobility (Godinho et al., 2014). It should be noted that the Ca return to the soil via litter decomposition is generally considered high in most tropical forests (Vitousek, 1984).

The lignin and cellulose contents, as well as the $\mathrm{C} / \mathrm{N}$ and $\mathrm{Lig} / \mathrm{N}$ ratios of the present study were lower than those found by Gama-Rodrigues et al. (2003), in litter from native forest species in Southeastern state of Bahia. According to Carvalho et al. (2012), organic 
compounds have their quality defined by means of chemical composition, where $\mathrm{C} / \mathrm{N}$ and $\mathrm{C} / \mathrm{P}$ and Lig/N ratios, as well as lignin, cellulose and hemicellulose levels, will influence the OM decomposition process and, consequently, the availability of nutrients to plants. Thus, the differentiation of the constituents of foliar plant material among these studies is influenced by the diversity of the evaluated species, where leguminous species stand out due to higher $\mathrm{N}$ concentrations in the plant material (Meirelles \& Souza, 2015). Therefore, the dominance of the Fabaceae family, with the occurrence of 44 species in the forest fragment under study (Archanjo et al., 2012), highlights the good quality of the leaf material for decomposition and nutrient cycling.

The leaf decomposition pattern was positively correlated with accumulated precipitation. Tropical forests with well-developed structure and presence of strata, provide microclimate favorable to the action of decomposing fauna of organic matter, thus, the more conducive for the microclimate in the accumulated litter, the greater the presence and activity of fauna and decomposing microorganisms (Menezes et al., 2009; Pereira et al., 2013). However, the correlation of decomposition with accumulated precipitation indicates that the response of the decomposition process to rainfall variation is not immediate, i.e. precipitation accumulation over time is the determining factor of greater importance. Thus, rainfall seasonality will determine the decomposition dynamics, directly regulating the activities of decomposing bodies, once the return of rainfall after a dry period increases the biodiversity of these organisms, providing an increase in the litter decomposition rate (Sanches et al., 2009).

In general, the fragment of the Atlantic Forest under study is characterized by great potential for nutrient cycling, especially $\mathrm{N}, \mathrm{P}$ and $\mathrm{K}$. This feature demonstrates fundamental importance for the maintenance of tropical forests, once the soils of these forests are naturally characterized by low natural fertility, being dependent on cycling that promotes nutrients digestion for reabsorption in a short period of time (Rodrigues et al., 2007; Cunha et al., 2009; Godinho et al., 2013a, 2013b).

\section{CONCLUSIONS}

Variations in leaflitter decomposition of Semideciduous Submontane Forest occurred in response to air temperature (average and minimum) and accumulated rainfall over time, due to the immediate responses of vegetation regarding precipitation.

The leaf material had rapid nutrient mineralization in the decomposition process, providing speed in the biogeochemical cycling of these nutrients in the tropical forest ecosystem.

\section{ACKNOWLEDGEMENTS}

The authors thank FAPES/CAPES Notice $\mathrm{N}^{\circ} 009 / 2014$, FAPES Notice $\mathrm{N}^{\circ} 02 / 2015$ - Research Fee, and CNPq Process $\mathrm{N}^{\circ} 303363 / 2015-0$ for funding the research, and IDAF for allowing the first author to conduct the research.

\section{SUBMISSION STATUS}

Received: 9 nov., 2018

Accepted: 4 dec., 2018

\section{CORRESPONDENCE TO}

\section{Diêgo Gomes Júnior}

Gerência Local de Alegre, Instituto de Defesa

Agropecuária e Florestal do Espírito Santo

- IDAF, Rua Olívio Correa Pedrosa, 566,

CEP 29500-000, Alegre, ES, Brasil

e-mail: diegogomesj@gmail.com

\section{FINANCIAL SUPPORT}

FAPES/CAPES Edital № 009/2014, FAPES Edital No 02/2015 - Taxa de Pesquisa, CNPq Processo No 303363/2015-0.

\section{REFERENCES}

Alvares CA, Stape JL, Sentelhas PC, Gonçalves JLM, Sparovek G. Köppen's climate classification map for Brazil. Meteorologische Zeitschrift 2013; 22(6): 711-728. http:// dx.doi.org/10.1127/0941-2948/2013/0507.

Alves RA, Souto JS, Souto PC, Holanda AC. Aporte e decomposição de serapilheira em área de Caatinga, na Paraíba. Revista de Biologia e Ciências da Terra 2006; 6(2): 194-203.

Anderson JM, Proctor J, Vallack HW. Ecological studies in four constrasting lowland rain forest in Gunung Mulu National Park, Sarawak. III. Decomposition processes 
and nutrient losses from leaf litter. Journal of Ecology 1983; 71(3): 503-527. http://dx.doi.org/10.2307/2259731.

Archanjo KMPA, Silva GF, Chichorro JF, Soares CPB. Estrutura do componente arbóreo da Reserva Particular do Patrimônio Natural Cafundó, Cachoeiro de Itapemirim, Espírito Santo, Brasil. Floresta 2012; 42(1): 145-160. http:// dx.doi.org/10.5380/rf.v42i1.26311.

Bachega LR, Bouillet JP, Piccolo MC, Saint-André L, Bouvet JM, Nouvellon Y et al. Decomposition of Eucalyptus grandis and Acacia mangium leaves and fine roots in tropical conditions did not meet the Home Field Advantage hypothesis. Forest Ecology and Management 2016; 359(1): 33-43. http://dx.doi.org/10.1016/j.foreco.2015.09.026.

Barbhuiya AR, Arunachalam A, Nath PC, Khan ML, Arunachalam K. Leaf litter decomposition of dominant tree species of Namdapha National Park, Arunachal Pradesh, northeast India. Journal Forest Restoration 2008; 13(1): 25-34. http://dx.doi.org/10.1007/s10310-007-0044-6.

Bauer D, Santos EL, Schmitt JL. Avaliação da decomposição de serapilheira em dois fragmentos de Caatinga no Sertão Paraibano. Pesquisas Botanica 2016; 69: 307-318.

Berchielli TT, Sader APO, Tonani FL, Paziani SF, Andrade P. Avaliação da determinação da fibra em detergente neutro e da fibra em detergente ácido pelo sistema ANKOM. Revista Brasileira de Zootecnia 2001; 30(5): 1572-1578. http://dx.doi.org/10.1590/S1516-35982001000600027.

Berg B. Litter decomposition and organic matter turnover in northern forest soil. Forest Ecology and Management 2000; 133(1): 13-22. http://dx.doi.org/10.1016/S03781127(99)00294-7.

Bocock KL, Gilbert OJW. The disappearance of litter under different woodland conditions. Plant and Soil 1957; 9(2): 179-185. http://dx.doi.org/10.1007/BF01398924.

Caldeira MVW, Silva RD, Kunz SH, Zorzanelli JPF, Castro $\mathrm{KC}$, Godinho TO. Biomassa e nutrientes da serapilheira em diferentes coberturas florestais. Comunicata Scientiae 2013; 4(2): 111-119.

Caldeira MVW, Vitorino MD, Schaadt SS, Moraes E, Balbinot R. Quantificação de serapilheira e de nutrientes em uma Floresta Ombrófila Densa. Semina: Ciências Agrárias 2008; 29(1): 53-68. http://dx.doi.org/10.5433/16790359.2008v29n1p53.

Calvi GP, Pereira MG, Espíndula A Jr. Produção de serapilheira e aporte de nutrientes em áreas de floresta atlântica em Santa Maria de Jetibá, ES. Ciência Florestal 2009; 19(2): 131-138. http://dx.doi.org/10.5902/19805098404.

Carvalho AM, Bustamante MMC, Sousa JGA Jr, Vivaldi LJ. Decomposição de resíduos vegetais em Latossolo sob cultivo de milho e plantas de cobertura. Revista Brasileira de Ciência do Solo 2008; 32: 2831-2838. http://dx.doi. org/10.1590/S0100-06832008000700029.

Carvalho AM, Coelho MC, Dantas RA, Fonseca OP, Guimarães R Jr, Figueiredo CC. Chemica lcomposition of cover plantsand its effect on maizeyield in no-tillage systems in the Brazilian savanna. Crop \& Pasture Science 2012; 63(11-12): 1075-1081. http://dx.doi.org/10.1071/ $\mathrm{CP} 12272$

Costa GS, Gama-Rodrigues AC, Cunha GM. Decomposição e liberação de nutrientes da serapilheira foliar em povoamentos de Eucalyptusgrandis no norte fluminense. Revista Árvore 2005; 29(4): 563-570. http://dx.doi.org/10.1590/S010067622005000400008 .

Cunha GM, Gama-Rodrigues AC, Gama-Rodrigues EF, Velloso ACX. Biomassa e estoque de carbono e nutrientes em florestas montanas da Mata Atlântica na região norte do estado do Rio de Janeiro. Revista Brasileira de Ciência do Solo 2009; 33(5): 1175-1185. http://dx.doi.org/10.1590/ S0100-06832009000500011.

Delarmelina WM. Fertilidade, estoque de carbono orgânico do solo e serapilheira em uma Floresta Estacional SemidecidualSubmontana [dissertação]. Jerônimo Monteiro: Ciências Florestais, Universidade Federal do Espírito Santo; 2015.

Diniz AR, Pereira MG, Loss A. Aporte de material decíduo e nutrientes para o solo em plantio de eucalipto e floresta secundária. Pesquisa Florestal Brasileira 2011; 31(65): 1926. http://dx.doi.org/10.4336/2011.pfb.31.65.19.

Franco AL, Bartz ML, Cherubin MR, Baretta D, Cerri $\mathrm{CE}$, Feigl BJ et al. Loss of soil (macro) fauna due to the expansion of Brazilian sugarcane acreage. The Science of the Total Environment 2016; 563-564(1): 160-168. http:// dx.doi.org/10.1016/j.scitotenv.2016.04.116. PMid:27135579.

Gama-Rodrigues AC, Barros NF, Santos ML. Decomposição e liberação de nutrientes do folhedo de espécies florestais nativas em plantios puros e mistos no sudeste da Bahia. Revista Brasileira de Ciência do Solo 2003; 27(1): 1021-1031. http://dx.doi.org/10.1590/S0100-06832003000600006.

Gilliam FS, Billmyer JH, Walter CA, Peterjohn WT. Effects of excess nitrogen on biogeochemistry of a temperate hardwood forest: evidence of nutrient redistribution by a forest understory species. Atmospheric Environment 2016; 146(1): 261-270. http://dx.doi.org/10.1016/j. atmosenv.2016.04.007.

Godinho TO, Caldeira MVW, Caliman JP, Prezotti LC, Watzlawick LF, Azevedo HCA et al. Biomassa, macronutrientes e carbono orgânico na serapilheira depositada em trecho de floresta Estacional SemidecidualSubmontana, ES. Scientia Forestalis 2013b; 41(97): 131-144.

Godinho TO, Caldeira MVW, Rocha JHT, Caliman JP, Trazzi PA. Quantificação de biomassa e nutrientes na serapilheira acumulada em trecho de Floresta Estacional SemidecidualSubmontana, ES. Cerne 2014; 20(1): 11-20. http://dx.doi.org/10.1590/S0104-77602014000100002.

Godinho TO, Caldeira MVW, Rocha JHT, Caliman JP, Vieira M. Fertilidade do solo e nutrientes na serapilheira em fragmento de Floresta Estacional Semidecidual. Revista 
Ecologia e Nutrição Florestal 2013a; 1(3): 97-109. http:// dx.doi.org/10.13086/2316-980x.v01n03a01.

Gomes D Jr. Dinâmica da serapilheira em fragmento de Floresta Atlântica, ES [tese]. Jerônimo Monteiro: Ciências Florestais, Universidade Federal do Espírito Santo, 2017.

Grugiki MA, Andrade FV, Passos RR, Ferreira ACF. Decomposição e atividade microbiana da serapilheira em coberturas florestais no sul do Espírito Santo. Floresta e Ambiente 2017; 24(0): 1-12. http://dx.doi.org/10.1590/21798087.018915.

Guimarães MAM, Calegário N, Carvalho LMT, Trugilho PF. Height-Diameter models in forestry with inclusion of covariates. Cerne 2009; 15(3): 313-321.

Guo LB, Sims REH. Litter decomposition and nutrient release via litter decomposition in New Zealand eucalypt short rotation forests. Agriculture, Ecosystems \& Environment 1999; 75(1-2): 133-140. http://dx.doi.org/10.1016/S01678809(99)00069-9.

Holanda AC, Feliciano ALP, Marangon LC, Freire FJ, Holanda EM. Decomposição da serapilheira foliar e respiração edáfica em um remanescente de caatinga na Paraíba. Revista Árvore 2015; 39(2): 245-254. http://dx.doi. org/10.1590/0100-67622015000200004.

Joslin A, Markewitz D, Morris LA, Oliveira FA, Kato O. Improved fallow: growth and nitrogen accumulation of five native tree species in Brazil. Nutrient Cycling in Agroecosystems 2016; 106(1): 1-15. http://dx.doi.org/10.1007/ s10705-016-9783-0.

Leco. C-144 carbon determinator - specification sheet 209134-003. Michigan: LECO Corporation; 2008.

Lima RP, Fernandes MM, Fernandes MRM, Matricardi EAT. Aporte e decomposição da serapilheira na Caatinga no Sul do Piauí. Floresta e Ambiente 2015; 22(1): 42-49. http://dx.doi.org/10.1590/2179-8087.062013.

Machado DL, Pereira MG, Correia MEF, Diniz AR, Santos LL, Menezes GCE. Nutrient cycling in different successional stages of forest atlantic, in river basin sul Paraiba, RJ. Bioscience Journal 2015; 31(4): 1222-1237. http://dx.doi.org/10.14393/BJ-v31n1a2015-23092.

Majumder M, Shukla AK, Arunachalam A. Nutrient release and fungal succession during decomposition of crop residues in a shifting cultivation system. Communications in Soil Science and Plant Analysis 2010; 41(4): 497-515. http://dx.doi.org/10.1080/00103620903495571.

Meirelles AC, Souza LAG. Produção e qualidade da biomassa de leguminosas arbóreas cultivadas em sistema de aleias em Latossolo Amarelo da Amazônia Central. Revista Brasileira de Agroecologia 2015; 10(2): 67-74.

Menezes CEG, Correia MEF, Pereira MG, Batista I, Rodrigues KM, Couto WH et al. Macrofauna edáfica em estádios sucessionais de floresta estacional semidecidual e pastagem mista em Pinheiral (RJ). Revista Brasileira de Ciência do Solo 2009; 33(6): 1647-1656. http://dx.doi. org/10.1590/S0100-06832009000600013.

Menezes CEG, Pereira MG, Correia MEF, Anjos LHC, Paula $\mathrm{RR}$, Souza ME. Aporte e decomposição da serapilheira e produção de biomassa radicular em florestas com diferentes estágios sucessionais em Pinheiral, RJ. Ciência Florestal 2010; 20(3): 439-452. http://dx.doi.org/10.5902/198050982059.

Myers N, Mittermeier RA, Mittermeier CG, Fonseca GAB, Kent J. Biodiversity hotspots for conservation priorities. Nature 2000; 403(6772): 853-858. http://dx.doi. org/10.1038/35002501. PMid:10706275.

Neto FVC, Leles PSS, Pereira MG, Bellumath VGH, Alonso JM. Acúmulo e decomposição da serapilheira em quatro formações florestais. Ciência Florestal 2013; 23(3): 379-387.

Nogueira LR, Goncalves JLM, Engel VL, Parrotta JA. Soil dynamics and carbon stocks 10 years after restoration of degraded land using Atlantic. Forest Tree Species 2011; 20(3): 536-545.

Olson JS. Energy-storage and balance of producers and decomposers in ecological-systems. Ecology 1963; 44(2): 322-331. http://dx.doi.org/10.2307/1932179.

Pereira GHA, Pereira MG, Anjos LHC, Amorim TA, Menezes CEG. Decomposição da serapilheira, diversidade e funcionalidade de invertebrados do solo em um fragmento de Floresta Atlântica. Bioscience Journal 2013; 29(5): 1317-1327.

R Core Team. $R$ : a language and environment for statistical computing [online]. Vienna: The R Foundation; 2016 [cited 2018 Nov 9]. Available from: https://www.r-project.org/

Rheinheimer DS, Anghinoni I, Kaminski J. Depleção do fósforo inorgânico de diferentes de diferentes frações provocada pela extração sucessiva com resina em diferentes solos e manejos. Revista Brasileira de Ciência do Solo 2000; 24(2): 345-354. http://dx.doi.org/10.1590/S010006832000000200012 .

Ribeiro MC, Metzger JP, Martensen AC, Ponzoni FJ, Hirota MM. The Brazilian Atlantic Forest: how much is left, and how is the remaining forest distributed? Implications for conservation. Biological Conservation 2009; 142(6): 1141 1153. http://dx.doi.org/10.1016/j.biocon.2009.02.021.

Rodrigues LA, Carvalho DAD, Oliveira-Filho ATD, Curi N. Efeitos de solos e topografia sobre a distribuição de espécies arbóreas em um fragmento de floresta estacional semidecidual, em Luminárias, MG. Revista Árvore 2007; 31(1): 25-35. http://dx.doi.org/10.1590/S010067622007000100004

Rumpel C, Kögel-Knabner I. Deep soil organic matter-a key but poorly understood component of terrestrial C cycle. Plant and Soil 2011; 338(1-2): 143-158. http:// dx.doi.org/10.1007/s11104-010-0391-5.

Sanches L, Valentini CMA, Biudes MS, Nogueira JS. Dinâmica sazonal da produção e decomposição de serapilheira 
em floresta tropical de transição. Revista Brasileira de Engenharia Agrícola e Ambiental 2009; 13(2): 183-189. http://dx.doi.org/10.1590/S1415-43662009000200012.

Scheer MB. Decomposição e liberação de nutrientes da serapilheira foliar em um trecho de Floresta Ombrófila Densa Aluvial em regeneração, Guaraqueçaba (PR). Floresta 2008; 38(2): 253-266. http://dx.doi.org/10.5380/ rf.v38i2.11620.

Sena ALM, Silva Neto AJ, Oliveira GMV, Calegario N. Modelos lineares e não lineares com uso de covariantes para relação hipsométrica de duas espécies de Pinus tropicais. Ciência Florestal 2015; 25(4): 969-980. http:// dx.doi.org/10.5902/1980509820651.

Silva AG, Gonçalves MAM, Reis EF. Decomposição e teor de nutrientes da serapilheira foliar em um fragmento de Floresta Atlântica no sul do estado do Espírito Santo.
Ecologia e NutriçãoFlorestal 2013; 1(2): 63-71. http:// dx.doi.org/10.13086/2316-980x.v01n02a02.

Stevenson FJ, Cole MA. Cycles of soil: Carbon, nitrogen, phosphorus, sulfur, micronutrients. 2rd ed. New York: John Wiley \& Sons; 1999.

Tedesco MJ, Gianello C, Bissani CA, Bohnen H, Volkweis SJ. Análise de solo, plantas e outros materiais. 2rd ed. Porto Alegre: Universidade Federal do Rio Grande do Sul; 1995.

Viera M, Schumacher MV, Araújo EF. Disponibilização de nutrientes via decomposição da serapilheira foliar em um plantio de Eucalyptusurophylla $\times$ Eucalyptusglobulus. Floresta e Ambiente 2014; 21(3): 307-315. http://dx.doi. org/10.1590/2179-8087.066313.

Vitousek PM. Litterfall, nutrient cycling, and nutrient limitation in tropical forests. Ecology 1984; 65(1): 285298. http://dx.doi.org/10.2307/1939481. 